\title{
Analysis of Development for Higher Education Internationalization
}

\author{
Xinlin $\mathrm{He}^{1, \mathrm{a}^{*}}$ and Miao Shang ${ }^{2, \mathrm{~b}}$ \\ 1, 2 Mechanical and Electrical Technology Department, Xijing University, Xi'an, China \\ a153789939@qq.com, ${ }^{\mathrm{b}} 445700839 @ q q . c o m$
}

Keywords: Internationalization of higher education; Education; Cross; Overseas investments; Student mobility

\begin{abstract}
The internationalization of higher education is an important form of higher education to achieve multinational. Economic globalization is both a driving force and the internationalization of higher education's background of the occurrence and development. With the rapid development of economy in our country and the continuous improvement of people's living standard, the internationalization of higher education needs in the direction of the global win-win development. In this article, the internationalization of higher education is briefly introduced. The types of higher education internationalization will be described. The current situation of the development of the internationalization of higher education will be analyzed. And the development of higher education internationalization direction will be pointed out. The internationalization of higher education needs to establish a multiple target to promote the development of global economy, maintenance of world peace and harmony. It also needs to implement elite higher education internationalization, popularization, professional, practical and greening. Analysis of development of higher education internationalization direction.
\end{abstract}

\section{Introduction of Higher Education International}

Higher Education Higher Education internationalization is important manifestations of transnational and means. The Internationalization of higher education among the countries of the degree recognition and certificate of approval or diploma education. The Internationalization of higher education, also known as the "Transnational Education". The League of Nations (GATE Transnational Education - the global alliance for transnational education) Transnational higher education is defined as: a State providing higher education in educational institutions in another country (host country) to provide students with learning activities [1]. The Internationalization of higher education is economic globalization - Higher Education internationalization - Transnational Higher Education- foreign cooperative sponsoring this relationship an important link in the chain. Economic globalization is not only the source of the Internationalization of higher education, it is also a matter of higher education and the development of the international event of epochal background.

\section{Nature of Internationalization of Higher Education}

The Internationalization of higher education of their students to other countries for their teaching activities. The Internationalization of higher education realized the goal of "Transnational Education". The essence of the Internationalization of higher education have also been analyzed from various angles [2].

Tertiary Education is a Phenomenon. This new phenomenon includes two distinct features. A cross-border nature or has no boundary. Jane knight considered that transnational higher education refers not only to transcend national geographic boundaries, also refers to transcend national borders, jurisdiction "cross-border education" can best express connotations [3]. Robin middle Hurst to virtual education in "Borderless Education" in the context of the current globalization that have emerged in the community of non-traditional core characteristics are beyond the range of the border, including in the areas of border (industry and education), the borders of the state, the border in the area of border, 
spatial and temporal, public and private border and so on. However, most scholars are widely shared transnational higher education is generally stressed that transcend national borders [4]. Technical personnel distribution as shown in Fig. 1.

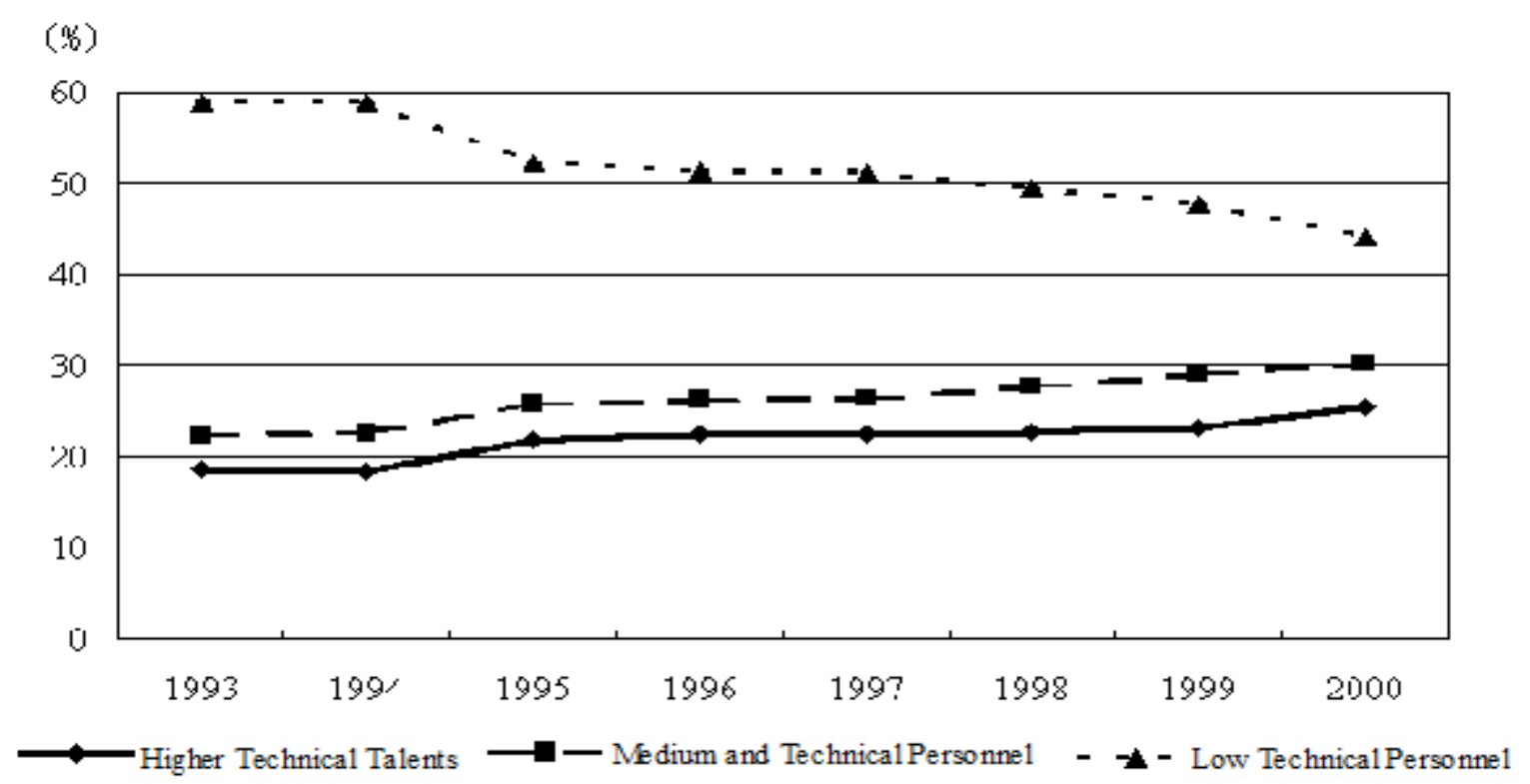

Figure 1. Technical personnel distribution

Higher Education Internationalization is regarded as a Process. This process is referred to as a national educational institutions and other educational institutions in countries in cooperation with an educational project, or through the establishment of an education branch, or via remote technologies output higher education a process. Institutions of higher education in a global context by this development and expansion of the force of the comprehensive influence and push and the process of globalization is closely related [5].

Higher Education Internationalization is regarded as Activities. Such activities include: the concessionaire sponsoring, project cooperation, UC Berkeley, such as overseas branches in the form of various types of schools. The first session of the trade in education services Forum proposed the "cross-border education" concept, and cross-border education activities summarized in the movement of people across borders, project the cross-border movement, institutions the cross-border movement three main forms.

\section{Internationalization of Higher Education Classification}

Higher education in accordance with the Institute's internationalization and is divided into different universities, training institutions and corporations. The main activities of these bodies to conduct overseas campus or overseas investment. These institutions, though from a low but the pace is very quick. The Internationalization of higher education by project, which is an education project [6]. The Internationalization of higher education to enable States to establish partnership between academic or e-learning. Students in Higher Education in the body of the internationalization of which accounted for the largest share. The types of activities that the students there are three main types of situations [7]. One is to obtain foreign degree or certificate of eligibility for full-time study; one is to achieve their own or joint degrees of learning; another kind is the exchange between the participating States. Professor is teaching staff. The main concern is the professor of vocational education in the mobility of personnel and the growing internationalization of. The work of the management is to help overseas projects or the functioning of institutions [8]. 


\section{Present State of Development in Internationalization of Higher Education}

The development of the higher education internationalization was complex and multidimensional. The Internationalization of higher education so that the output of the parties with the input of the parties there are obvious differences between. Even if the same output as input the same party or parties that the development of the higher education internationalization of also vary with the national interests of a different focus [9]. Further analysis, even in the same country within the countries, institutions and individuals, and the level of the same level as well as the orientation of pluralism. The Internationalization of higher education development concept is motivated by the combined effects of the results. The legitimate development concept to not only make the same country within different hierarchy of needs for the interest of balance, also need to be balanced against the interests of both the cooperation and purpose. Of course, one country transnational higher education development philosophy will vary depending on the country's economic, educational, cultural, social and political developments should change with the time, showing a dynamic and multi-dimensional. In 2003, norway held at the second session of trade in education forum" on transnational higher education in the four development concept [10].

International Understanding of Concept that Promotion of Different Countries. Different races and different beliefs of the people of the linkages between, and the mutual understanding, strengthen their cooperation to promote economic, educational, cultural, and social aspects of sustainable development. The Western countries to contain the implementation in higher education for educational exchanges and cooperation as the promotion of peace, enhance mutual understanding, the consolidation of relations between States, output values of the important means [11].

Human Resources Development Philosophy. Through transnational higher education to attract and develop their human resources. The United States, Canada and some European countries to transnational higher education as a selection, attract outstanding students studying overseas talent strategy. States through programs and to provide scholarships for outstanding students to attract talents. For example: In the United States to give priority to providing scholarships to graduate or high-skilled students and for information technology professionals priority visa. The United States Congress by the end of 2004 submitted a copy of the United States aimed at the strengthening of tertiary education and international exchange and cooperation in education in the proposals emphasized: The expansion of American values to the whole world, strengthening of the United States on the world leaders, higher education involving the countries of the world, is the best people in the field of higher education for the United States to strengthen international exchanges and cooperation between the three main objectives.

Obtain Economic Interests of Philosophy, which emphasizes the development of higher education through transnational rich institutions of higher education are a source of revenue for the Government to remedy the shortcomings of the input of funds or through the development of higher education in transnational new markets, expanding the international education market share. In some OECD countries, especially Australia, New Zealand and the United Kingdom to the development strategy, chasing the economic interests of the thinking is very conspicuous. They are all well recognized higher education industry and market attributes, education is regarded as export industries is that higher education exports can increase revenue to make up for the inadequacy of funding for education, and preserve the trade balance. To this end, they have a variety of cardholders initiatives in support of education and higher education students cross development.

\section{Emerging and Developing of Countries Transnational Higher Education}

Emerging and Developing of Countries Transnational Higher Education as an important means of strengthening capacity building, the main reasons: (1) to attract foreign direct investment has contributed to the improvement of national education infrastructure. (2) The Transnational higher education helps to increase their supply capacities of the higher education system and the upgrading of the quality of the supply. Consequently, different countries or in the same countries at different 
times policy along with its development philosophy of the changes. (3) Introduction of foreign high-quality education resources conducive to enhancing national institutions of teaching, curriculum design and management capabilities as well as the research capacity for enhancing the quality of teachers. (4) Tertiary education through participation in a transnational, targeted introduction of fine foreign resources, conducive to the promotion of economic development and national capacity-building and closely related to the field of development.

\section{Development of Higher Education Internationalization Direction}

Higher Education Higher Education internationalization is important manifestations of transnational and means. Economic globalization is not only the source of the Internationalization of higher education, it is also a matter of higher education and the development of the international event of epochal background. As our country's rapid economic development, as constantly improve the living standards of the people, and the higher education needs of internationalization toward global win direction. At the same time, in the course of economic globalization, driven by higher education internationalization has become an irresistible trend. Higher education is to spread across the globe. The development of higher education in different from that in the past the new characteristics in different countries and different groups. The Internationalization of higher education, it is necessary to establish the promotion of global economic development, the multiple goals of maintaining world peace and harmony. The Internationalization of higher education also needs to implement the kind of elitism, the popularization, specialization, commercialization and green.

\section{References}

[1] H.Y.Liu: U DP Proportion Higher Education and Social Policy Research, Vol. (2012), P. 27-28.

[2] J.B.Wang, H.T.Yang:New Field of Overseas Investment-New Trend of Transnational Higher Education (DongYue Review, China, 2012)

[3] Verbik L, Merkley C: Intematinal Branch Campus - Models and Trends, Observatory on Borderless (Higher Education Report, China, 2006).

[4] B.C.Ji:Our Country's Higher Education Scale Forecast Analysis in 2020, Vol. 1 (2011) No. 1, p. 305.

[5] L.J.Guo: Under Globalization of Transnational Higher Education-Point of View, Problems and China's Response (China Social Sciences Press, China, 2009)

[6] G.S.Yi: University Chinese-Foreign Cooperation in Running Schools Mode and Operation Mechanism of Research (Shanghai University Publishing House, China 2007.)

[7] Benoit Minogue: Higher Education Spending and Output-Complexity of Relationship, Peking University Education review, Vol. 2 (2013), 60.

[8] X.J.Guo: Transnational Education Development Concept and Strategy (Stanford university press, China, 2008)

[9] G.P.Feng: Transnational Education-International Comparative Study (Shanghai People's Publishing House, China ,2010)

[10] Y.L.Xie : Soul of European Universities Classification, Comparative Education Research, Vol.4 (2010), p. 45.

[11] Henry m. levin. Education How to Adapt to Future-Background of American Education, Peking University Education Review, Vol. 2 (2013), p. 2-3. 